Vol. 7 No. 2 Juli 2018

E-ISSN : 2502-3101 P-ISSN : 2302-528x

http://ojs.unud.ac.id/index.php/jmhu

\title{
The State Responsibilities Relating to Human Rights Violations to The People with Stateless Persons Status in Rohingnya Crisis
}

\section{Putu Dwika Ariestu1}

${ }^{1}$ Faculty of Law, Mahendradatta University, E-mail: dariestu41@gmail.com

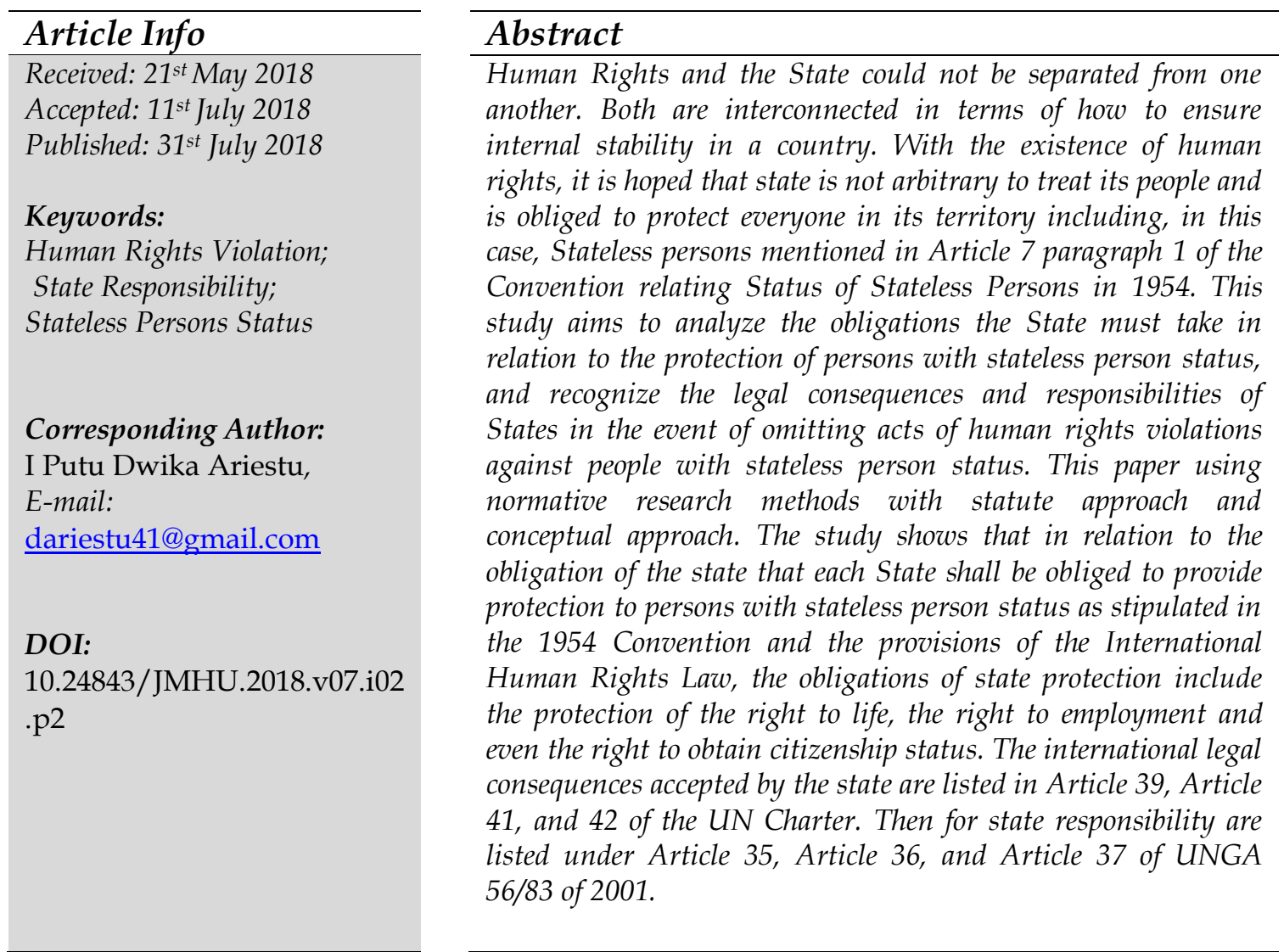

\section{Introduction}

Del Vasechio in A. Masyhur Efendi states that man is ius iurdicus (human law), because the law and man throughout his life can never be separated if the man wants to live safe, peaceful, peaceful, just and prosperous. Law in the broad sense penetrate into the whole of human life, both in the most elementary things, simple, and into the deepest and most basic things. ${ }^{1}$

${ }^{1}$ Marudut, T. Aswanto, Manuputty, A. (2013). Perlindungan Hak Asasi Manusia (HAM) Terhadap Hak Tersangka Dalam Lembaga Praperadilan, Jurnal Penelitian Hukum Universitas Hasanudin, 2 (3). p. 394 
Robert Audi stated, Efforts to respect, protect, and uphold human rights, become a duty and a shared responsibility between individuals, governments, and even countries. So, in fulfilling and demanding rights could not be separated from the fulfillment of obligations that must be implemented. Also, in order to fulfill individual interest could not damage the interests of the people (public interest). Therefore, the fulfillment, protection, and respect for human rights must be followed by human rights and human rights responsibilities in private, community, and state life. ${ }^{2}$

The Magna Charta Charter (England) in 1215 which constituted a limited monarchical power. The law came into force not only for the people but also for the nobility and the royal family. The Magna Charta Charter, also called Magna Charta Libertatum (The Great Charter of Freedoms) was made during the reign of King John of England and applies to the next ruling British kings. The main content of the document is that the king shall not infringe any personal property and personal freedom of the people. In addition to Magna Charta also contains the affirmation that "no one shall be arrested or imprisoned or expelled from his country or destroyed without being judicially prosecuted by judges equal to him" (judicium parjum suorum) ${ }^{3}$

According to Philip M. Hadjon, the human rights of the Western concept which is essentially a restriction on the conduct of the state and its organs and the laying of state obligations against its citizens so that the principles contained in the concept of human rights are claims of the right to the state and the obligations which must be done by the state. ${ }^{4}$ Human Rights Violations is a very prominent issue and most often discussed both in the regional and global forum today. During the history of human civilization that has been going on to date, there are many cases of human rights violations that have been done either actors who perform are individuals or countries. The main focus of this research is the responsibility of the state, and in this case, the state as the subject of international law.

State responsibility is a fundamental principle in international law that based on he doctrine of international jurists. The State Responsibility arises when there is a breach of an international obligation to do something, whether such obligations under international treaties or in accordance with international customs. ${ }^{5}$ In addition, state responsibility arises as a result of the principle of equality and sovereignty of statements contained in international law. ${ }^{6}$ This principle then gives authority to a country whose rights are violated to claim a right that is in the form of reparation. ${ }^{7}$

Human Rights and the State could not be separated from one another. Both are interconnected in terms of how to ensure internal stability in a country. With the existence of human rights, the state is expected not to arbitrarily treat its people and is obliged to protect everyone in its territory including in this case people with status

2 El-Muhtaj, M. \& Hum, M. (2017). Hak Asasi Manusia dalam Konstitusi Indonesia. Prenada Media. Jakarta. p.50

${ }^{3}$ Ibid, p. 52

${ }^{4}$ Hadjon, P. M. (1987). Perlindungan Hukum bagi Rakyat Indonesia. Bina Ilmu. Surabaya. p. 61.

${ }^{5}$ Sujatmoko, A. (2005). Tanggung Jawab Negara Atas Pelanggaran Berat HAM: Indonesia, Timor Leste dan Lainnya. Grasindo Gramedia Widiasarana Indonesia. Jakarta. p. 28.

${ }^{6}$ Hingorani (1984). Modern International Law. Second Edition. Oceana Publications. USA. p. 241.

${ }^{7}$ Ibid. 
Stateless (stateless persons) it is mentioned in Article 7 paragraph 1 Convention Relating to Status of Stateless Persons in 1954, stating that: 8

"Except where this Convention contains more favourable provisions, a Contracting State shall accord to stateless persons the same treatment as is accorded to aliens generally".

The same treatment is an implementation of the principle of Non-Discrimination contained in this Convention, expressed as follows: "The Contracting States shall apply the provisions of this Convention to stateless persons without discrimination as to race, religion or country of origin.

Subsequently, the state's responsibilities relating to the title of this study shall be governed by United Nations General Assembly Resolution Number 56/88 of 12 December 2001 on the State's Responsibility for Non-Conforming Acts, hereinafter referred to as GA Resolution 56/58 2001. Although, in this case, there are international law instruments that have been previously published there are still doubts in the protection of human rights against persons with stateless status, especially for countries that do not ratify the Convention Relating to the Status of Stateless Persons 1954 and the Convention on the Reduction of Statelessness 1961. A recent concrete case of Rohingnya ethnic slaughter in Myanmar's Rakhine district. Here's a news quote about Rohingnya case: ${ }^{9}$

"UN Secretary General Antonio Guterres said the Myanmar government should grant citizenship status to Rohingya or the legal status that allows them to live a normal life. Guterres expressed his concern about excessive military power during security operations in Myanmar's Rakhine state. It asked for "immediate steps" to end the violence.

"I ask the Myanmar authorities to suspend military action, end the violence, uphold the rule of law and recognize the right to return all those who must leave the country," Guterres said at a news conference. Asked why he chose the Rohingya ethnic cleansing term, Guterres replied: "When a third of the Rohingyas must flee from their country, can you find a better word to describe it?". Rohingya has a population of 1.1 million and years of discrimination in Myanmar. They are denied their citizenship even though many have long historical roots in the country ".

According to the case above, Myanmar is responsible for cleansing Rohingnya ethnic and deliberately providing no protection against its ethnic spirits so that these ethnic people have no nationality. Until now there is still no good faith from the Myanmar government in order to solve the cases that occurred in their country. Hundreds of thousands of people looking for other uses for the moment have no nationality.

The Rohingnya Crisis began when the first batch of more than 200,000 Rohingyas fled Myanmar in 1978, Bangladesh saw it as a humanitarian crisis, and arranged temporary

8 Convention Relating Status of Stateless Persons 1954

9 CNN Indonesia, 2017, PBB Desak Myanmar Beri Status Kewarganegaraan Rohingnya, article: 14 September 2017, accesed via website:https://www.cnnindonesia.com/internasional/20170914041910-106-241605/pbbdesak-myanmar-beri-status-kewarganegaraan-rohingya, dated : 18 April 2018. 
shelters and other supports for the refugees. In the second phase, during 1991-1992 when 250,000 Rohingyas fled to Bangladesh after the serious state repression in the Northern Rakhine State of Myanmar, the Government of Bangladesh granted temporary asylum as well as providing food and medical services to Rohingya refugees. The government also called on humanitarian aid from the United Nations High Commissioner for Refugees (UNHCR) for those refugees. ${ }^{10}$ The Rohingya crisis once again became a burning issue after the clashes between the Buddhists and Muslims in The Rakhine state of Myanmar in 2012.45 More than 100,000 people were displaced due to the violence since June 2012.11

From the case above can be explained that the State does not provide protection and even tend to arbitrarily until ethnic cleansing action arises within the country, then the ethnic is also not recognized as citizens this means the ethnic have stateless persons status. Based on the background above, the formulation of problems that can be raised in this study are as follows:

- What are the obligations to be performed by the State in order to protect persons with stateless persons status who are victims of human rights violations in their country?

- What are the legal consequences and responsibilities imposed by the State in relation to the omission of human rights violations by persons with stateless person status under international legal instruments?

Concerning the originality of the research, this research was written based on preexisting journals which can be described as follows: 1. Andrés Ordoñez Buitrago in the Journal entitled "Statelessness and Human Rights: The Role of the United Nations High Commissioner of Refugee (UNHCR)" in this case discusses the role of UNHCR in tackling the increasing number of stateless persons with human rights approaches and international provisions;12 2. David Weissbrodt and Clay Collin, in the journal entitled "The Human Rights of Stateless Person", discusses the rights to stateless persons listed in various provisions of human rights instruments. ${ }^{13}$

The general objective of this study is to assess the responsibility of the state in violations of human rights directed against persons with stateless persons status in the scope of international law, while the specific objectives of this study are to examine What are the obligations the State should make in order to protect persons who is a stateless person and also a victim of human rights violations in his or her country, and What are legal consequences imposed by the State in the event of omission human rights violations by persons with stateless person status according to international legal instruments.

\footnotetext{
${ }^{10}$ Ragland, T.K. (1994). Burma's Rohingyas in Crisis: Protection of Humanitarian Refugees under International Law, Boston College Third World Law Journal. 14(2). p.310.

${ }^{11}$ Yesmin, S. (2016). Policy Towards Rohingnya Refugees: A Comparative Analysis of Bangladesh, Malaysia. and Thailand, Journal of the Asiatic Society of Bangladesh (Hum.), 61(1). p. 80.

12 Ordoñez Buitrago, A. (2012). Statelessness and human rights: the role of the United Nations High Commissioner for Refugees (UNHCR). Ejil - EAFIT Journal of International Law. 2(2). 723.

${ }^{13}$ Weissbrodt, D. S., \& Collins, C. (2006). The human rights of stateless persons. Human Rights Quarterly, 28(1), 245-276.
} 


\section{Research Methods}

According to William H. Putman, "Legal research is a part of the legal analysis process. It is the legal analysis process that involves finding the law that applies the legal question by the facts of client's case. "14 This research is done by doing literature research, or commonly known as the literature study, although the research in question could not be separated from another sources, for example like mass media materials or from the internet. The author also uses the juridical approach method, by studying the applicable legal provisions as well as what happens in reality in society. This study uses statute approach. Since the International Law does not recognize the term law, the statute approach here is broadly defined so that the laws written in international law can be exemplified as international conventions, international agreements or other binding written documents. Then the next approach used concept approach (conceptual approach).

\section{Result and Discussion}

\subsection{State Obligations in Protection of People with Stateless Persons Status}

Each Rohingya is being persecuted due to state's repression and is also unwilling to avail himself of the protection of that country. Myanmar's two most brutal campaigns against Rohingyas namely 'Operation Dragon King (1978)' and 'Operation Pyi Thaya (1991-1992) created risk of persecution in their state of origin through mass killing and expulsion of Rohingyas from their land which led thousands of Rohingyas to flee as well as seek refuge in another place..$^{15}$ Later, in the mid-2012, another case of violence against Rohingyas once again led them to seek refuge in neighboring countries. The United Nations, therefore, defines Rohingyas as the most persecuted community in the world. Sultana Yesmin M. Phil Candidate, Department of International Relations from University of Dhaka in her Journal stated, "However, Rohingyas are not recognized as "refugee" in neighbouring countries. They are rather also labeled "illegal immigrants" and "economic migrants" as well. Rohingyas are also defined with different concepts. For example, sometimes Rohingyas are called as 'stateless persons' under the 1954 UN Convention relating to the status of statelessness because they do not belong to any nationality of any country. Following the irregular movements of a arge number of Rohingyas towards Southeast Asian countries through sea routes, Rohingyas are also termed as 'boat people'. ${ }^{16}$

Dr. Martin Stiller is a Candidate Lawyer from Finanzprokuratur in Vienna, Austria in his journal: Statelessness in International Law: A Historic Overview quotes the meaning of stateless persons from Oppenheim: ${ }^{17}$

"The difficulties for stateless persons are readily identifiable: without nationality, no genuine link can be established; without a genuine link, there is no state eligible to exercise its diplomatic protection. Oppenheim, therefore, stated correctly that stateless persons "may be compared to vessels on the open sea not sailing under the flag of a State, which likewise do not enjoy any protection."

14 Putman, W. H. (2009). Legal Research: Second Edition. Delmar. United States of America. p. 372.

15 Parnini, S. N., Othman, M. R., \& Ghazali, A. S. (2013). The Rohingya refugee crisis and Bangladesh-Myanmar relations. Asian and Pacific Migration Journal, 22(1), 133-146. p. 136.

16 Yesmin, S. (2016). Op.Cit. p. 74

17 Stiller, M. (2012). Statelessness in International Law: A Historic Overview. Deutsch-Amerikanische Juristenvereinigung (DAJV) Newsletter $3^{\text {rd }}$ Edition. Bonn. p. 95 
It can be said that persons with stateless persons status are persons with no nationality at all, have no connection with any country, and do not enjoy or get protection from any country because of their status. Then Katja Swinder a Ph.D. candidate from the University of Amsterdam in his journal entitled: Protection and Identification of Stateless Persons through EU Law, states: 18

"The UN defines a stateless person as a person 'who is not considered as a national by any State under the operation of its law'.3 It is a negatively formulated definition, where statelessness is described in terms of an absence of the legal status of nationality. Such a definition requires further elaboration in order to be implementable in practice. Proving that one is not a national of any state in the world is virtually impossible. Therefore, when applying the definition of a stateless person to a particular individual, the concept of 'any State' needs to be narrowed down".

Other problems experienced by Stateless Person are violations of their rights by the State as regulated in the Convention relating to the Status of Stateless Person 1954. Because Stateless Person is not a citizen of the country in which they live, they are often rejected to obtain basic rights and access to employment, shelter, education, and health. They could not own property, get married officially or register the birth of their child. Some of them are held for long periods of time because of their inability to prove who they are and where they are from. In practice they often do not get identity documents, detained because of their status as a Stateless Person, are denied access to education and health services or prevented from getting a job: ${ }^{19}$

The state's obligation to protect persons with stateless persons status under the Convention relating to the Status of Stateless Person 1954:20

- States Parties shall apply the entire contents of the Convention without discrimination against race, religion, country of origin (Art 3) and treat stateless persons as citizens in freedom of religion and education for their children (Art 4).

- After 3 years of stay, stateless persons shall be entitled to be exempt from legislative reciprocity in the territories of participating countries (Art 7).

- States parties shall consider providing an opportunity for stateless persons who work as crew aboard their country's flag to settle in its territory and issue travel documents or temporary permits to reside in its territory (Art 11).

- The personal status of stateless persons is subject to the laws of the country in which it is domiciled or resident and the State Party shall respect the rights previously acquired and related to its personal status in accordance with the legal formalities of the participating member countries (Art.12).

- States parties shall treat stateless persons as best they can, no less than the treatment of foreigners in respect of the acquisition of movable or immovable property, together with other related rights including in the case of leases and other contractual forms of movable or immovable property (Art 13).

18 Swinder, K. (2014) Protection and Identification of Stateless Persons through EU Law. Amsterdam Centre for European Law and Governance Working Paper Series 2014 - 05. Amsterdam. p. 4.

${ }^{19}$ Lewa, C. (2008). Asia's New Boat People, Forced Migration Review. London: Refugee Studies Centre University of Oxford. V. 30. p. 40.

20 Indonesian Journal of International Law. (2004). International Law Making: Convention Relating to the Status of Stateless Persons, Indonesian Journal of International Law. 2(1). p. 188. 
Some of the articles above are articles that generally state the state's obligation in the treatment of stateless persons residing within its territory under the 1954 Convention. Most of the articles contained in the 1954 Convention are the implementation of The Universal Declaration of Human Rights 1948, especially in the case of individual rights, politics rights and economics rights. In the book UNHCR Commemorating the Refugee and Statelessness Convention especially about obligations of non-participating countries are stated as follows:

"States that are not party to the 1954 Convention are nonetheless bound by provisions of international human rights law to respect the rights of stateless persons within their territory (for example, the prohibition against arbitrary detention pursuant to Article 9(1) of the ICCPR and the obligation to ensure that every child has a nationality pursuant to Article 24(3) of the ICCPR and Article 7(1) of the CRC). Statelessness is, therefore, a juridically relevant fact in this context. Moreover, non-party States may find it useful to establish statelessness determination procedures and a number have actually done so. In addition, such States may find helpful guidance in the provisions of the 1954 Convention with respect to their response to statelessness, for example, with regard to the provision of identity and travel documents to stateless persons".

In this case neither the participating countries of the 1954 Convention nor those of the participating countries have an obligation to protect the human rights of persons with stateless persons status. All human rights within each person should be respected as well as those with stateless persons status. This obligation is undertaken in an attempt to prevent acts of state violations against persons with stateless persons.

\subsection{Legal Consequences and State Responsibility Conducting to Omission of Human Rights Violations against Persons with Stateless Persons Status According to International Law}

In determining what conduct is attributable to the State under the international law of State responsibility, we normally work from specific behavior of particular government officials acting alone or in concert. Because the abstract "State" acts only through "agents" in control of the State or some part of its apparatus, any such acts of those individuals are attributed to the State if done under actual or apparent authority of the State. Brownlie states, responsibility of the State engages when such conduct causes harm in breach of international obligation. ${ }^{21}$

The 1954 Convention recognizes the international legal status of "stateless persons". Article 1 sets the formula for stateless persons in international law: a person "who is not considered a citizen by any State in the exercise of the law of that State". This formula is now also recognized as customary international law. Persons who fulfill this definition are entitled to certain rights and obligations contained in the 1954 Convention. This Convention does not include so-called persons who are de facto stateless, which are not contained in the formulas accepted common in international law. However, people who are de facto with no citizenship are entitled to protection under international human

${ }^{21}$ Christenson, G. A. (1990). Attributing Acts of Ommision to the State. Va. J. Int'l L.. 12. p. 312. 
rights law. The Refugees are covered by the 1951 Convention on the Status of Refugees and should be treated in accordance with international refugee law. ${ }^{22}$

The right to have nationality is a fundamental right for every human being, it is mentioned in Article 15 UDHR. The right to citizenship is also mentioned in the Covenant on Civil and Political Article 24 which states that every child must be registered immediately after his birth and that every child has the right to nationality. In the 1965 Convention on the Elimination of all forms of racial discrimination, everyone without exception and without distinction of race, color, genetic origin, nation or ethnicity shall be entitled to citizenship. ${ }^{23}$

In the 1954 Convention there is a clause that not every person with stateless persons' status of protection is provided in Article 1 of the 1954 Convention stipulates that there are certain circumstances in which stateless persons do not benefit from the status of persons without nationality and protection from This Convention. It is referred to as an "exception" and applies to persons who do not require or do not deserve international protection, for example because there are good reasons to consider that they have committed a criminal offense against peace, war crimes, or crimes against humanity. Special rules apply to a special category of stateless persons, who like other stateless people need international protection, but for them have been set up separate arrangements for protection or assistance. ${ }^{24}$

In the context of International Law the legal consequences accepted by the state which in this case indirectly threaten the security, order and peace of the world then under Article 39 of the Charter of the United Nations states:

The Security Council shall determine the existence of any threat to the peace, breach of the peace, or act of aggression and shall make recommendations, or decide what measures shall be taken in accordance with Articles 41 and 42, to maintain or restore international peace and security.

Then in Articles 41 and 42 of the UN Charter are the implementation of measures that the Security Council may take in the event of threats to world peace, order and security, including:

Art 41

The Security Council may decide what measures not involving the use of armed force are to be employed to give effect to its decisions, and it may call upon the Members of the United Nations to apply such measures. These may include complete or partial interruption of economic relations and of rail, sea, air, postal, telegraphic, radio, and other means of communication, and the severance of diplomatic relations.

Art 42

Should the Security Council consider that measures provided for in Article 41 would be inadequate or have proved to be inadequate, it may take such action by air, sea, or land forces as

22 UNHCR. (2010). Melindungi Hak-hak Orang-orang Tanpa Kewarganegaraan: Konvensi 1954 Tentang Status Orang-orang Tanpa Kewarganegaraan. UNHCR. Geneva. p. 4.

${ }^{23}$ See Article 5 Item d (iii) of the 1965 Convention on the Elimination of All Forms of Racial Discrimination See Article 5 Item d (iii) of the 1965 Convention on the Elimination of All Forms of Racial Discrimination

${ }^{24}$ UNHCR," Melindungi Hak-hak..., Op.Cit, p.6 
may be necessary to maintain or restore international peace and security. Such action may include demonstrations, blockade, and other operations by air, sea, or land forces of Members of the United Nations.

Referring to the articles above if the State omits acts of human rights violations against stateless persons and from such actions creates a threat to world peace, security and order, then the Security Council may restore the situation under Article 39, Article 41, and Article 42 of the UN Charter. The actions taken by the Security Council in the form of termination of economic relations, the termination of trade routes either by sea or air, the termination of the telecommunication network may even lead to the dismissal of diplomatic relations under Article 41. While if the action of Article 41 is ineffective then the Security Council may take military action either through land, sea or air with forms of demonstration, blockade or other acts that can be carried out by military forces both land, sea or air, aimed at restoring security, order and world peace.

In relation to the responsibility of the State, the responsibility that must be taken by the state in the event of an omission of serious human rights violations committed to stateless persons may be made to ensure that such action does not recur in accordance with United Nations General Assembly Resolution 56/83 of 2001 (UNGA 56 / 81) article 30 , as well as the responsible country, must thoroughly recover from the damage inflicted by UNGA 56/81 Article 31. In the journal written by Milka Dimitrovska LLM. Vladimir Ortakovski stated that in relation to the responsibility of the state, the responsibility that the State must take in the event of an omission serious human rights violations directed against stateless persons can be made to ensure that such acts are not repeated under the United Nations General Assembly Resolution 56/83 of 2001 (hereinafter UNGA 56/81) article 30, as well as the responsible state obliged to rehabilitation of the damage imposed by UNGA 56/81 Article 31. In a journal written by Milka Dimitrovska it is stated that: ${ }^{25}$

There are three basic forms of reparations based on commission of internationally wrongful acts which are: restitution, compensation and satisfaction, but their combination is also possible. (UNGA Resolution 56/83, Art. 34). Reparations may vary qualitatively, but they do not have retributive caracter. The priority is assigned to the restitution, i.e. returning to previous condition restitutio in integrum as far as possible, while the area that cannot be covered by the institution of restitution, compensation will be paid.

There are three responsibilities which the state must take in order to restore conditions arising from wrongful acts under international provisions, such as restitution, compensation and repayment and each of them is ordered in accordance with UNGA 56/83 Article 35, Article 36 and Article 37.

\section{Conclusion}

From the description that has been mentioned above, the authors can conclude several matters relating to the formulation of the problems listed in this paper: in this case each State shall be obliged to provide protection to persons with stateless persons status

${ }^{25}$ Ortakovski, V., \& Milenkovska, M. (2014). International public law. Skopje. Faculty of security ñ Skopje. p. 130. dalam Dimitrovska, M. (2015). The concept of international responsibility of state in the international public law system. Journal of Liberty and International Affairs. 1(2). 8-23. p. 9. 
whether or not the country is a member of the 1954 Convention, this is because the obligation to protect and reduce the number of persons with stateless persons status is a necessity even the country is not a member country so they remain bound by the provisions of international human rights law. In general, the obligation to be carried out by the state is the guarantee of the protection of the human rights of persons with stateless persons status whether it is the right to life, the right to exercise their religion, the right to gain employment, even the right to obtain citizenship status.

Legal consequences which the State receives in the event of omission of acts of human rights violations occurring in the country against persons with stateless persons status may be subject to Article 39, Article 41, and Article 42 of the UN Charter, the UN Security Council may undertake efforts to safeguard and restore world peace in case there is a threat to world security. Consequences received by the state can be termination of economic relations, termination of communication, diplomatic termination, and the most severe is the embargo. The responsibilities imposed on the state pursuant to UNGA 56/83 of 2001 shall be in the form of restitution, among other things, in the form of restitution, compensation and repayment by the state as a result of losses suffered by persons with stateless person status.

\section{Bibliography}

\section{Books}

El-Muhtaj, M. \& Hum, M. (2017). Hak Asasi Manusia dalam Konstitusi Indonesia. Prenada Media. Jakarta

Hingorani. (1984). Modern International Law. Second Edition. Oceana Publications. USA.

Philipus, M. H. (1987). Perlindungan Hukum Bagi Rakyat Indonesia. Bina Ilmu, Surabaya.

Putman, W. H. (2009). Legal Research: Second Edition. Delmar. United States of America

Sujatmoko, A. (2005). Tanggung Jawab Negara Atas Pelanggaran Berat HAM: Indonesia, Timor Leste dan Lainnya. Grasindo Gramedia Widiasarana Indonesia. Jakarta

Swider, K. (2014). Protection and identification of stateless persons through EU law. Swider, Katja, Protection and Identification of Stateless Persons Through EU Law (July 9, 2014). Amsterdam Centre for European Law and Governance Research Paper No. 2014-05. http://dx.doi.org/10.2139/ssrn.2464009

UNHCR. (2012). Commemorating the Refugee and Statelessness Convention. UNHCR Division of International Protection. Geneva

UNHCR. (2010). Melindungi Hak-hak Orang-orang Tanpa Kewarganegaraan: Konvensi 1954 Tentang Status Orang-orang Tanpa Kewarganegaraan. UNHCR. Geneva

\section{Journals}

Christenson, G. A. (1991). Attributing acts of omission to the state. Mich. J. Int'l L., 12, 312-370. 
Dimitrovska, M. (2015). The concept of international responsibility of state in the international public law system. Journal of Liberty and International Affairs. 1(2). $8-23$

Indonesian Journal of International Law. (2004), International Law Making: Convention Relating to the Status of Stateless Persons. Indonesian Journal of International Law, 2 (1).

Lewa, C. (2008). Asia's new boat people. Forced Migration Review, 30, 40-42.

Marudut, T. Aswanto, Manuputty, A. (2013). Perlindungan Hak Asasi Manusia (HAM) Terhadap Hak Tersangka Dalam Lembaga Praperadilan, Jurnal Penelitian Hukum Universitas Hasanudin, 2 (3).

Ordoñez Buitrago, A. (2012). Statelessness and human rights: the role of the United Nations High Commissioner for Refugees (UNHCR). Ejil - EAFIT Journal Of International Law, 2(2), 7-23.

Parnini, S. N., Othman, M. R., \& Ghazali, A. S. (2013). The Rohingya refugee crisis and Bangladesh-Myanmar relations. Asian and Pacific Migration Journal, 22(1), 133146. https://doi.org/10.1177/011719681302200107

Ragland, T.K. (1994). Burma's Rohingyas in Crisis: Protection of Humanitarian Refugees under International Law, Boston College Third World Law Journal. 14(2)._301336.

Stiller, M. (2012). Statelessness in International Law: A Historic Overview. DAJV Newsl., 37, 94.

Weissbrodt, D. S., \& Collins, C. (2006). The human rights of stateless persons. Human Rights Quarterly, 28(1), 245-276.

Yesmin, S. (2016). Policy Towards Rohingya Refugees: A Comparative Analysis of Bangladesh, Malaysia and Thailand. Journal of the Asiatic Society of Bangladesh (Hum.), 61(1), 71-100.

Website

Prima Gumilang. (2017, September 14). PBB Desak Myanmar Beri Status Kewarganegaraan Rohingnya. CNN Indonesia https://www.cnnindonesia.com/internasional/20170914041910-106241605/pbb-desak-myanmar-beri-status-kewarganegaraan-rohingya accessed 18 April 2018 